\title{
Equity-Bond Yield Correlation and the FED Model: Evidence of Switching Behaviour from the G7 Markets
}

February 2018

Revised April 2018

This Version June 2018

\begin{abstract}
$\underline{\text { Abstract }}$
This paper considers how the strength and nature of the relation between the equity and bond yield varies with the level of the real bond yield. We demonstrate that at low levels of the real bond yield, the correlation between the equity and bond yields turns negative. This arises as the lower bond yield implies heightened macroeconomic risk (e.g., deflation and economic stagnation) and causes equity and bond prices to move in opposite directions. The FED model relies on a positive relation for its success in predicting future returns. Thus, we argue that the mixed empirical evidence regarding the FED model arises due to this switch in correlation behaviour. We present supportive evidence for the switching relation and its link to the level of the bond yield using linear and non-linear smooth transition panel regression techniques for the G7 markets. The results presented here should be of interest to market practitioners who may wish to use the FED model to aid market timing decisions and for academics interested in understanding the interrelations between markets.
\end{abstract}

Keywords: Equity Returns, Bond Returns, Correlation, Bond Yield, Switching

JEL: C22, C23, E44, G12, G15 


\section{Introduction.}

The FED model implies a positive relation between the equity and bond yields. It is of importance to practitioners given its potential to predict subsequent stock returns and to academics given its implications about cross-asset behaviour. However, both theoretical models and empirical evidence remains mixed. We argue, this arises as the relation between the two yields is better characterised as a non-linear one that is related to economic conditions. We present evidence in support of a switch in the stock and bond yield correlation. The strength of the correlation is linked to the bond yield and a non-linear FED model improves the predictive power for stock returns. A key implication of the analysis suggests that during very low levels of the bond yield, the FED model can break down such that the equity and bond yield relation no longer predicts future stock returns.

A current debate within the literature regards both the theoretical and empirical validity of the FED model and the positive equity and bond yield relation. This includes Asness (2003) who argues against the FED model from a theoretical basis, because long term bond yields are a claim on a nominal income stream while equity is a claim on real assets. Counter to this, the presence of a money illusion effect (Campbell and Vuolteenaho, 2004; Sharpe, 2001; Ritter and Warr, 2002) is used to explain the positive relation between the yields on the two assets. Thomas and Zhang (2008) use the dividend growth model (Gordon, 1962) to relate earnings yields to bond yields in support of the FED model. Moreover, they provide empirical evidence in which the two yields move together during periods of stable risk and growth rates. This implies that periods where such co-movement is absent are characterised by shifts in risk or growth. ${ }^{1}$ Asness argues that the positive relation disappears over a longer time horizon. Estrada (2006) similarly shows that the FED model has relatively weak predictive power for future stock returns. In

\footnotetext{
${ }^{1}$ Asness (2000) similarly finds empirical evidence of a risk adjusted relation between earnings and bond yields.
} 
contrast, a range of empirical evidence supports the model. This includes Bekaert and Engstrom (2010) who report supportive evidence across a range of international markets and Thomas and Zhang (2008) who argue that the FED model is theoretically consistent and produces useful information regarding stock price valuation. More recently, Maio (2013) provides evidence for the success of the FED model in forecasting stock returns. ${ }^{2}$

Stock and bond yields are typically considered to exhibit a positive correlation as they are exposed to similar macroeconomic conditions such as inflation, real interest rates and economic growth (for a discussion see Chiang et al., 2015). However, a negative correlation during periods of heightened macroeconomic risk can arise as bonds become more attractive and investors move funds from the stock to the bond market, creating a flight-to-safety effect (for a discussion see, inter alia, Baur and Lucey, 2009; Hakkio and Keeton, 2009; Chiang et al., 2015). Moreover, while a flight-to-safety argument can explain the negative stock and bond yield correlation over a short horizon, a prolonged negative correlation may be rooted in a general change in the economic environment. Over the recent past, very low and partially negative real interest rates might reflect a sustained shift in risk aversion and expected economic stagnation (for a discussion see, Humpe and McMillan, 2016). Recent studies relate the decline in real bond yields over recent years to a secular decline in economic trend growth (see, Laubach et al., 2003) and increased risk aversion (see, Laubach, 2009). As such, the low real bond yields currently observed reflect expected economic stagnation and precautionary savings due to high risk aversion (for a discussion see, Hamilton et al., 2016).

Such a switch in the stock-bond relation was identified by Gulko (2002) and this paper continues the empirical examination of the FED model and the underlying equity and bond

\footnotetext{
${ }^{2}$ Support for the positive equity and bond yield relation is also provided by work examining the Bond (Gilt) Equity Yield Ratio (BEYR or GEYR). See, for example, Clare et al (1994), Levin and Wright (1998), Harris (2000), Brooks and Persand (2001) and McMillan (2009, 2012).
} 
yield relation. Our first hypothesis states that the observed time-varying correlation between the two yields is linked to the level of the bond yield, which acts as an indicator for economic conditions. Building upon this, our second hypothesis examines whether the FED model provides any predictive power for one-step ahead stocks returns. Subsequently, in the third hypothesis, we seek to account for the time-varying relation between the equity and bond yields by utilising a non-linear, smooth transition, model.

To analyse these issues, we utilise data from the G7 markets and implement panel regression techniques. To obtain a time-varying correlation series between the equity and bond yields, we use the dynamic conditional correlation approach. Furthermore, we consider real instead of nominal values to avoid any confounding effects from money illusion. We then examine the behaviour of these time-varying dynamic conditional correlations and seek to determine whether they exhibit any relation with the bond yield. Subsequently, this then motivates our stock return and FED model predictive regression, including both the linear and non-linear approaches.

\section{Background.}

The FED model is an equity valuation approach that compares the earnings yield of a stock market index with long-term government bond yields of the same country. It was named the FED model after it appeared in the Humphrey-Hawkins report issued by the Federal Reserve in July 1997. ${ }^{3}$ The Federal Reserve Chairman Alan Greenspan argued that the stock market valuation was too high because the decline in earnings yields was not matched by a fall in 10 year government bond yields. In the investment community, the FED model is used as a market timing indicator to switch between bonds and equities. Investors should buy equities when the

\footnotetext{
${ }^{3}$ Source: https://www.federalreserve.gov/boarddocs/hh/1997/july/reportsection2.htm
} 
difference between earnings yields and bond yields is above its long-term average and switch to bonds when it is below average. However, we argue that the model breaks down during periods of low inflation and interest rates.

Using the Gordon (1962) dividend growth model, Thomas and Zhang (2008) link the equity yield with the bond yield, generating a positive relation:

$\frac{d_{1}}{p_{0}}=r-g=r_{f}+r_{p}-g=r r_{f}+i+r_{p}-g$

Where $p_{0}$ is the stock price at the end of year 0 ex-dividend, $d_{1}$ is the dividend paid in the following year, $g$ the expected nominal dividend growth rate sustainable in perpetuity, $r$ the required rate of return for investing in equities (equal to $r_{f}+r_{p}$ ), $r_{f}$ long-term nominal risk-free rate (consisting of the real risk-free rate $r r_{f}$ plus inflation $i$ ) and $r_{p}$ is the risk premium demanded by investors for holding equities. To adjust the model to allow the earnings yield rather than dividend yield, the authors substitute the dividend growth rate $g$ with $g_{f p}$, the dividend growth rate that can be sustained in perpetuity under a full payout policy. Thus, $g_{f p}$ is the relevant growth rate for nominal earnings yields:

$\frac{e_{1}}{p_{0}}=r-g_{f p}=r_{f}+r_{p}-g_{f p}=r r_{f}+i+r_{p}-g_{f p}$

Where $\frac{e_{1}}{p_{0}}$ is the earnings yield, with the other terms defined above. As the FED model implies that the earnings and nominal bond yields move together, the implication is that risk premium $r_{p}$ and growth effects $g_{f p}$ must remain stationary, as it seems unlikely that they move together. Thomas and Zhang (2008) present empirical evidence in support of stable risk and growth effects during periods where the two yields exhibit a strong positive correlation. In contrast, periods where co-movement is absent are characterised by shifts in risk or growth. Asness (2000) also reports empirical evidence of a risk adjusted relation between earnings and bond yields described by the following equation:

$\frac{e_{1}}{p_{0}}=a+b Y+c \sigma_{\text {stocks }}-d \sigma_{\text {bonds }}$ 
Where $r r_{f}+i$ is represented by the long-term nominal government bond yield $\mathrm{Y}$ and the terms $\sigma_{\text {stocks }}$ and $\sigma_{\text {bonds }}$ are the prior realised 20-year standard deviations of stock and bond returns respectively. The hypothesis and subsequent statistical evidence supports that $b$ and $c$ are positive and $d$ is negative. With $c$ positive and $d$ negative, Asness concludes that investors set the earnings yield as a function of nominal interest rates, but they also require a higher earnings yield versus bond yield when their generation has experienced relatively more volatility in stocks compared to bonds (Asness, 2003).

Based on the above evidence presented by Thomas and Zhang (2008) and Asness (2000, 2003), we argue that the relation between bond and equity yields is itself related to the real bond yield. Recent studies relate the decline in real bond yields over recent years to a secular decline in economic trend growth (see, inter alia, Laubach et al., 2003) and an increased risk aversion (see, inter alia, Laubach, 2009). The rationale given is that greater risk aversion will raise the spread of risky over risk-free yields by raising the demand for safe assets relative to that for risky ones resulting in lower Treasury yields. Hence, real bond yields incorporate both expected trend growth and risk aversion. Therefore, low real bond yields reflect expected economic stagnation and precautious savings due to high risk aversion (for a discussion see, inter alia, Hamilton et al., 2016). In such an environment, we would expect earnings yields to rise rather than fall in common with bond yields and thus inducing a negative correlation between the two yields. In contrast, at higher levels of the real bond yield that are associated with higher economic growth and lower risk aversion, stock and bond yields would exhibit increased comovement (see, Thomas and Zhang, 2008).

The literature argues that stock and bond yields are generally positively correlated as both markets are exposed to similar macroeconomic conditions such as inflation, real interest rates and economic growth (for a discussion see, Chiang et al., 2015). Moreover, wealth effects, for example, encourage investors to hold stocks and bonds simultaneously and thus induces co- 
movement between bond and equity yields. Supportive empirical evidence is provided by, inter alia, Kwan (1996), d'Addona and Kind (2006) and Campbell and Ammer (1993). In contrast, a negative correlation between bond and equity yield is reported during periods of high volatility as stock and bond premiums diverge. Here, bonds become more attractive and investors move funds from the stock market to the bond market, creating a flight-to-safety effect (for a discussion see, Baur and Lucey, 2009; Hakkio and Keeton, 2009, Chiang et al., 2015).

However, flight-to-safety is generally associated with a temporary effect, such as the Russian bond default or the fall of Long Term Capital Management, that triggers a sudden drop in investors' risk appetite and increases risk aversion (for a discussion see, Beber et al., 2009). Hence, the phenomenon is regarded as concentrated in time. For instance, Gubareva and Borges (2016) define the maximum duration of flight-to-safety events as only 45 working days. Similarly, Gulko (2002) studies the decoupling effect between stocks and bonds during stock market crashes and finds that the flight-to-safety effect typically lasts two to three weeks. Thus, while the flight-to-safety effect is a rational argument for explaining temporary periods of a negative stock and bond correlation, it fails to explain prolonged periods of such a negative correlation. Instead, a prolonged negative equity-bonds correlation might be rooted in a general change in the economic environment. In this paper we contribute to the literature by linking the prolonged negative equity-bonds yield correlation in G7 markets to very low and partially negative real interest rates that may reflect a sustained shift in risk aversion and expected economic stagnation.

This paper extends the empirical examination of the FED model and the underlying equity and bond yield relation. Our interest lies in uncovering time-variation within the nature of the relation, which we believe, also explains why different authors report conflicting evidence in favour of stock return predictability arising from the FED model. Thus, we examine whether the correlation between the equity and bond yields varies over time and whether this 
variation is linked to the level of the bond yield, which acts as an indicator for economic conditions and inflationary expectations. Extending this analysis, we examine whether the FED model provides any predictive power for one-step ahead stocks returns. Moreover, we consider this in both the usual linear regression framework and a non-linear smooth transition model, which will capture the time-variation in the relation discussed above.

This paper utilises data from the G7 markets and implements panel regression techniques to examine these issues. To obtain a time-varying correlation series between the equity and bond yields, we use the dynamic conditional correlation (DCC) model. Furthermore, we use real values instead of nominal values to avoid any confusion that may arise from a money illusion effect. We then examine the behaviour of the time-varying DCC and whether it exhibits any relation with the bond yield. Subsequently, this motivates our FED model approach and the implementation of a non-linear model.

\section{Empirical Methodology.}

We begin our analysis by obtaining the time-varying real equity/bond yield correlation using the dynamic conditional correlation (DCC) model of Engle (2002). An alternative would be to consider a standard rolling Pearson correlation to capture the time variation, however, it suffers from two notable drawbacks. First, such correlation estimates adjust slowly to new information given the equal weighting of observations in Pearson correlations. Second, unusually small or large return observations will not gradually diminish over time, but instead lead to jumps in the correlation estimates when these observations drop out of the estimation window and, moreover, might depend on the market volatility (for a discussion, see inter alia, Forbes et al., 2002; Andersson et al., 2008). The DCC model is explained in appendix A.

To use the estimated correlation series as our dependent variable in a regression framework, we apply the generalized logit transformation. This is because correlations are 
bounded between -1 and 1 while the variables on the right-hand side of the regression are not. The generalized logit transform therefore widens the range of possible values for the correlation variable (for a discussion see, Andersson et al., 2008). The logit transformed correlations are obtained by:

$\rho_{t}=\log \left(\frac{1+\operatorname{Cor}(x, y)}{1-\operatorname{Cor}(x, y)}\right)$

Having obtained this time-varying correlation and to ensure the empirical validity of the subsequent results, we apply panel unit root tests to verify the order of integration. Specifically, we utilise the panel tests that allow for individual unit root processes of Im, Pesaran and Shin (2003) and Fisher (1932). For a discussion of the panel unit root tests, see appendix B.

Having considered the stationarity (or otherwise) properties of the series, we first conduct panel regressions of the stock-bond correlation against the bond yield as such:

$$
z_{i, t}=\alpha+\beta b y_{i, t}+\gamma_{i}+\delta_{t}+\varepsilon_{i, t}
$$

where $z_{i, t}$ represents the logit transformed DCC correlation between equity and bond returns for market $i$, and $b y_{i, t}$ represents the real bond yield. The terms $\gamma_{i}$ and $\delta_{t}$ refer to the cross-section and period-specific fixed effects, which effectively estimate the cross-sectional and periodspecific means.

Although we begin our analysis of the relation between the equity/bond correlation and the bond yield by considering a fixed effects panel regression model, we nonetheless verify its applicability through the Hausman test, which has a null hypothesis of random effects against the alternative of fixed effects. The test is built upon the fact that under the hypothesis of uncorrelated individual errors with the regressors, the OLS and GLS estimates are consistent, but OLS is inefficient (Hausman 1978). In contrast, under the alternative, OLS is consistent while GLS is not. Hence the null hypothesis of the Hausman test is no systematic difference between the OLS and GLS estimates.

Having established any relation between the correlation and the bond yield, we 
subsequently examine the ability of the FED model to predict stock returns. Initially, this is conducted through a linear panel regression equivalent to equation (5) but with stock returns as the dependent variable and a lag of the FED model as the explanatory variable. However, given the nature of the relation between the equity/bond correlation and bond returns, we believe the stock return and FED model relation will be better characterised as being non-linear. Thus, we estimate a panel smooth transition regression model (PSTR) to allow for such non-linearity. The PSTR model has several appealing features, as it allows for a smooth (non-linear) transition between regimes. In standard switching models, changes in regime are abrupt, implying that market participants act simultaneously. However, a smooth transition between regimes allows for the more intuitive outcome that different traders within the market act at different points in time. Furthermore, unlike Markov switching models, where regime changes are unobservable and governed by a Markov process, the STR model allows switching behaviour to depend upon observable variables (Humpe and Macmillan, 2014). The PSTR model (Gonzalez et. al 2005) with two extreme regimes has the form:

$y_{i, t}=\mu_{i}+\beta_{0}^{\prime} x_{i, t}+\beta_{1}^{\prime} x_{i, t} g\left(q_{i, t} ; \Upsilon ; c\right)+u_{i, t}$

with

$g\left(q_{i, t} ; \Upsilon ; c\right)=\left(1+\exp \left(-\Upsilon \prod_{j=1}^{m}\left(q_{i, t}-c_{j}\right)\right)\right)^{-1}, \quad \Upsilon>0, \mathrm{c}_{1} \leq \ldots \leq \mathrm{c}_{\mathrm{m}}$

where $y_{i, t}$ is a scalar, $\mu_{i}$ represents the fixed individual effects, $x_{i, t}$ is a $k$-dimensional vector of time-varying exogenous variables and $u_{i, t}$ are the errors. Furthermore, the continuous transition function $g\left(q_{i, t} ; \Upsilon ; c\right)$ is normalized to be bounded between zero and one, with the transition variable $q_{i, t}$, the slope parameter $Y$ and the vector of location parameters $c$. We model a generalization of this basic structure that allows for $r$ transition functions and considers 
exogenous variables with constant coefficients (for a discussion see Gonzalez et. al 2005). ${ }^{4}$ In order to overcome the problem of unidentified parameters when imposing $\gamma=0$ and $\beta_{1}=0$ in testing linearity against PSTR, a first-order Taylor expansion can be applied around $Y$ for $g\left(q_{i, t} ; \Upsilon ; c\right)$ in equation (6) and leads to the following auxiliary regression:

$y_{i, t}=\mu_{i}+\beta_{0}^{\prime *} x_{i, t}+\beta_{1}^{\prime *} x_{i, t} q_{i, t}+\cdots+\beta_{m}^{\prime *} x_{i, t} q_{i, t}^{m}+u_{i, t}^{*}$

Testing the null hypothesis of linearity $H_{0}^{*}: \Upsilon=0$ in equation (8) is now equivalent to testing $H_{0}^{*}: \beta_{1}^{\prime *}=\cdots=\beta_{m}^{\prime *}=0$ in (6). A LM test and F-version of the test can be computed by the residual sum of squares of the OLS estimates from equations (5) and (8):

$L M=T N\left(S S R_{0}-S S R_{1}\right) / S S R_{0}$ and $F=\left(S S R_{0}-S S R_{1}\right) / m k / S S R_{1} /(T N-N-m k)$

Under the null the distributions for the LM test is given by $\varkappa_{m k}^{2}$ and by $F(m k, T N-N-m k)$ for the F test. Furthermore, a pseudo-LRT test with $\mathcal{\varkappa}_{m k}^{2}$ distribution can be computed by: pseudo $-L R T=-2 \log \left(S S R_{1}-S S R_{0}\right)$.

\section{Data and Empirical Results.}

\subsection{Data}

For our empirical analysis of the FED model, we make use of monthly stock market trailing 12-month earnings yields and 10-year government interest rates for the individual G7 countries obtained from DataStream. For the equity markets we use broad indices that cover approximately $80 \%$ of the market cap according to Datastream. The number of stocks in the equity index are Germany (250), Canada (250), France (250), Italy (160), Japan (1000), UK (550) and US (1000). For real earnings yields and real bond yields we subtract the IMF YoY inflation rate (CPI all items) from the nominal interest rate and nominal earnings yields

\footnotetext{
${ }^{4}$ All the PSTR estimations are performed on the RATS software using GTVD.SRC, a program provided by Gilbert Colletaz whom we are grateful for having made it available on: http://www.univorleans.fr/deg/masters/ESA/GC/gcolletaz_R.htm
} 
respectively. The sample period is from January 1986 until January 2014. For the equity/bond yield conditional correlation, the data starts in April 1986. We also obtain stock return data over the full sample period to examine the ability of the FED model to predict returns. Table 1 shows the summary statistics of the variables.

\subsection{Step 1: Establishing the Relation between Bond/Equity Yield Correlation and Bond Yield} The plots of the unconditional ${ }^{5}$ and conditional (DCC) correlations are shown in Figure 1 and 2 and reveal periods of both positive and negative correlations. Moreover, the negative correlation periods are not just confined to the recent crisis period. That said, in general the correlations are positive in the first half of the sample, prior to 2000, and negative afterwards. However, there are exceptions to this for all countries, with Germany and Italy exhibiting the greatest amount of cycling between positive and negative correlations (this is more observable in the rolling correlations than in the DCC ones). Putting these plots in context, prior to 2000 equity prices were rising and particularly so during the late 1990s with the so-called dotcom bubble. After 2000 (when the bubble burst) equity prices fell, before rising between, approximately, 2003-2006. The latter part of the sample is marked by the financial crisis where equity prices fell from late 2007 to early 2009 before recovering. With respect to the bond market, bond yields have generally been on a downward trend since 1990, although with noticeable increases in the mid- and late-1990s and the period immediately prior to the financial crisis. The onset of the crisis further exacerbated this downward trend.

Having obtained the DCC correlation for each market we conduct panel unit root tests to test for stationarity. We consider an individual constant and trend effect in the data. Overall, the hypothesis of non-stationarity is mostly rejected for G7 equity-bond yield correlation and

\footnotetext{
${ }^{5}$ For illustration purposes, we show here the 48-month unconditional Pearson correlation.
} 
the real bond yield. ${ }^{6}$ Hence, in the panel regression analysis we can use the correlation data in levels. To establish the relation between the real equity/bond yield DCC correlation and the real bond yield, we estimate a pooled regression with different assumptions regarding the nature of the cross section and period effects. Table 2 column (a) reports results of equation (5) for the G7 sample where the pooled regression includes cross section fixed effects. This regression supports our hypothesis as it yields a statistically significant positive relation between the equity/bond correlation and the bond yield. Thus, a rising real bond yield is consistent with a strengthening positive correlation between equity and bond yields, while a falling bond yield can lead to a negative correlation. To assess the reliability of the model, we conduct the Hausman test for random effects in the cross section (country) series. Reported in the lower part of Table 2 (a), we can see that the Hausman test for cross section random effects is not rejected. Therefore, we re-estimate the model with random effects, the results of which are reported in Table 2 column (b). The cross section random effects model confirms the statistically significant positive relation between equity-bond yield correlations and the real bond yield. We also consider the possibility of period effects in Table 2 column (c), here, the Hausman test rejects the need for period random effects. Therefore, for completeness we estimate a pooled regression with random cross section effects and period fixed effects. With this specification the statistically significant positive relation between the equity-bond yield correlation and the real bond yield is once again confirmed.

To further support the robustness of the positive relation between stock-bond yield DCC correlations and real interest rates, we also estimate the model with lagged correlation on the right-hand side of the equation to directly account for any autocorrelation in the correlation. This methodology has been used by, inter alia, Li (2002). Following the same procedure as

\footnotetext{
${ }^{6}$ For space considerations we do not tabulate the results but they are available upon request.
} 
before, the results reported in Table 2 columns (d-f), with the exception of period fixed and cross section random effects, confirm the statistically significant positive relation between stock-bond correlations and real interest rates. However, the Hausman test indicates the possibility of period random effects. Therefore, we also estimate different period random effects specifications, with the results reported in Table 2 columns (g-i). The results further support a statistically significant positive relation between DCC and the real bond yield across all three slope coefficients.

As an additional robustness check on our results, we follow the alternative methodological approach that is considered by Andersson et al. (2008). Here, the relation between the correlation and the bond yield includes a lagged $\mathrm{AR}(1)$ error term specification for each individual market. The results of this approach are reported in Table 3, from which we can again observe a positive and statistically significant relation between the equity/bond correlation and real bond yields. We can also observe a higher degree of dependence within the country specific AR(1) terms.

Overall, across the full set of regression results that examine the relation between the equity/bond correlation and the real bond yield, we can confirm our first hypothesis and report a robust positive relation across the $\mathrm{G} 7$ markets. This implies a falling equity-bond yield correlation when the real bond yields fall, with a negative correlation at very low bond yields. As discussed earlier, the FED model postulates that bond and equity yields should be (highly) correlated and move in concert over time (for a discussion see Bekaert and Engstrom, 2010). In contrast, our results suggest that at (very) low real interest rates equity and bond yields tend to drift apart, such that the FED model is likely to break down in such an environment.

\subsection{Step 2: Stock Returns and the FED Model}

The above sub-section details the potential for the equity and bond yield to move apart. Before 
examining the implications for stock return predictability and the FED model, we consider the relation between the FED model (the difference between the real equity yield and real bond yield) and the real bond yield. Again, prior to estimating the regression models, we conduct a series of panel unit root tests to ensure stationarity of the variables. The results, available upon request, confirm the stationarity of the FED, the adjusted FED model and stock returns, having previously confirmed stationarity of real bond yields. ${ }^{7}$

Examining the relation between the FED model and the real bond yield, we find a negative and statistically significant coefficient value for the G7 markets, as reported in Tables 4 and 5 across different specifications of the panel model. This suggest that at (very) low real bond yields, the difference between equity and bond yields (FED spread) can increase to elevated levels. The results for the adjusted FED model are reported in Tables 6 and 7 and present results that reach the same conclusion. Namely, that there is a negative relation between the adjusted FED and the bond yield, such that at low levels of the yield, then the equity and bond yields move apart. At higher levels of the bond yield then the equity and bond yields move together with increasing strength.

The above results strongly support the conclusion that at higher levels of the bond yield the positive relation between the two yield series becomes stronger, while at (very) low levels of interest rate the relation becomes negative, as a result of increased risk. In addition, a rise in rates from very low levels is often accompanied by rising equity prices as they signal a return to normal economic conditions. As advocated by Blanchard (1981), higher bond yields might signal higher inflation and economic growth, which would have a positive impact on earnings. If this positive effect on share prices outstrips the negative one due to a higher discount rate, equities rise despite higher bond yields. However, a rise in rates from normal or high levels has

\footnotetext{
${ }^{7}$ As the equity yield accounts for an income stream arising from real assets, we also consider the FED model as the spread between the nominal equity yield to real bond yield and refer to this as the adjusted FED model.
} 
a negative effect on equity prices due to an increase in the discount rate and an increase in macroeconomic risk arising from a late cycle overheating economy. Inevitably, this changing behaviour between the equity and bond yield relation will affect the ability of the FED model to predict future stock returns.

Given these results, we argue that the predictive relation between expected future stock returns and the FED spread will vary according to the level of the real bond yield. To examine this second hypothesis, we estimate pooled linear and non-linear regressions with fixed effects for 1-year, 2-year, 3-year, 5-year and 10-year ahead G7 real stock market returns. To account for heteroscedasticity and autocorrelation, we apply White period standard errors and covariance. A similar methodology for the linear long-horizon stock market predictability and the FED model has been used by, inter alia, Maio (2013). The results of our regressions are reported in Table 8. The results reveal that with respect to the standard linear FED model there exists a positive and significant relation for future one year and two year real returns. This is consistent with the usual view that a higher FED value is consistent with a lower current stock price and higher expected future returns. However, for the three-year and longer forward returns, the FED coefficient turns negative and significantly so for the five-year horizon. This suggests an inconsistency in how the FED model predicts expected stock returns.

The short term positive and long term negative relation between the FED model and future stock returns might imply a business cycle effect. During recessions, stock prices tend to fall sharply and P/E ratios contract while the opposite occurs in economic booms. At the same time interest rates fall during recessions and rise during recovery and booms. Hence, the FED spread might be large during economic downturns and then falls over the recovery and expansion phase of the economy. As a result, the FED spread might be inversely correlated to the business cycle and thus the changing relation over different time horizons noted above. The average G7 business cycle length (trough-to-trough or peak-to-peak) of the post-war period is 
5.5 years (for a discussion see Artis et al. 1997). However, the business cycle is highly asymmetric with an average recession period of 15 -months followed by a 52-month expansion period. As the FED spread might be interpreted as a business cycle indicator, it is rational to expect a positive relation between the FED model and stock returns for shorter time horizons and a negative one for longer time horizons. The FED spread will be particularly high during recessions and indicate high stock returns for subsequent years as the economy recovers. In contrast, during booms the FED spread might be low and indicates lower future stock return as the economy begins to contract.

\subsection{Step 3: Non-linear stock returns predictability and the FED Model}

This inconsistency in linear predictability motivates consideration of the non-linear panel smooth transition regression model (PSTR) and our third hypothesis of non-linear stock market predictability arising from the FED model. We consider both the real bond yield and the FED model as potential threshold variables as well as allowing for up to two threshold points. Tests for the presence of non-linearity support such behaviour across all different stock return horizons when using the FED model as the threshold variable with two transition points. When allowing for one transition point then linearity is only supported at the 1-year horizon. The results for the real bond yield as the threshold variable indicate non-linearity at all horizons, except the 1-year, regardless of the number of transition points. ${ }^{8}$

Table 8, therefore, reports the results of allowing for two transition points for both threshold variables. The model fit measured by the $\mathrm{R}^{2}$ improves for all PSTR models compared to the linear models over the 1,2 and 3 years horizons. It can be observed that the $\mathrm{R}^{2}$ peaks at 5 years and then rapidly declines for 10 years. A similar pattern is observed by Campbell et al.

\footnotetext{
${ }^{8}$ The full set of test statistics is available upon request.
} 
(1997) for long-horizon predictive regressions between US stock returns and short-term interest rates. This may again support the business cycle hypothesis outlined above. Generally, the bond market has been found to deliver more accurate predictions about economic growth than the stock market (Harvey, 1989). Fisher (1907) suggests that, in equilibrium, the one-year interest rate reflects the marginal value of income today in relation to its marginal value next year. If a recession is expected next year, there is an incentive to sacrifice consumption today and buy the bond that pays off in the recession. Hence, the demand for the bond will increase bond prices and lower bond yields. This theory implies that current real interest rates contain information about expected economic growth and is further developed in consumption-based asset pricing models (for a discussion see, Campbell et al. 2000).

The results show that with the real bond yield as transition variable, a positive relation between the FED spread and future returns is noted in the middle regime of the PSTR model and a negative coefficient in the outer regime. Hence, at normal levels of the bond yield the positive relation of the FED spread with future stock returns is confirmed. However, with more extreme values of the real bond yield the FED coefficient, while remaining positive (except the 5-year horizon) weakens. This might suggest that the typical business cycle effect is overlaid by a structural effect during prolonged economic stagnation. In such a case, a large FED spread does not indicate high stock returns in the future, because lasting economic stagnation outpaces the business cycle effect. At normal levels of the bond yield the results indicate a positive short term and a negative long term relation that could be triggered by the business cycle. However, the PSTR model results also suggest that at extreme values of the bond yield the relation weakens. Hence, an unusually large or small bond yield rather points to prolonged economic issues of disinflation or overheating. When considering the FED spread as transition variable in the PSTAR models, we find a positive relation between stock returns and the FED model across all regimes and horizons, except for the inner regime for 1-year subsequent returns. 
Furthermore, except for the 3-year forward returns, we find a stronger effect in the outer regime across all horizons.

Overall, across the two sets of non-linear regressions we find a positive relation between stock returns and the FED model. Moreover, consistent with the arguments above, we note that the strength of the relation between stock returns and the FED model varies over time according to the level of real bond yield or the FED spread itself. Notably, we can see that the strength of the relation declines at more extreme values of the bond yield.

As a final exercise, to provide comparability between our results and earlier studies by, inter alia, Campbell and Shiller $(1988,2001)$ or Shen (2000), we estimate the relation of aggregate price earnings ratios (PE Ratio) and future stock returns as well (see Table 9). In line with the literature, the PE ratio is able to explain almost $40 \%$ of future stock returns over 10 years. For example, Campbell and Shiller (2001) report an $\mathrm{R}^{2}$ of $40 \%$ between the aggregate US stock market PE and 10-year forward returns during 1872 and 1997. Similarly, Campbell, Lo and MacKinlay (1997) report a $\mathrm{R}^{2}$ of $43 \%$ for long-horizon regressions between 4-year forward stock returns and the dividend-price ratio between 1952 and 1994 in the US. However, the $\mathrm{R}^{2}$ for shorter time horizons is generally much smaller and the above cited articles support only long-horizon return predictability for PE ratios. We also find a rapidly declining $\mathrm{R}^{2}$ for 5year, 2-year and 1-year forward returns. Comparing the predictability of the FED model with the PE ratio, we find that the FED model performs better than the PE ratio over 1, 2 and 3-year forward returns while the opposite is true for 5 and 10-year forward return. In line with the finding that the bond market delivers more accurate predictions about economic growth and the business cycle than the stock market (Harvey, 1989), our results support the view that the PE ratio does poorly in predicting stock returns over shorter horizons that are consistent with the typical length of the business cycle. In contrast, the FED model appears better able to capture business cycle effects through its inclusion of bond yields in its construction. However, over 
long horizons the business cycle effect is more negligible and the PE ratio performs better in predicting stock returns.

\section{Summary and Conclusion.}

This paper examines the nature of the relation between real equity and bond yields. A positive relation between them underlies the FED model, which is argued to have potential predictive power for future stock returns. A debate surrounds both the theoretical validity and empirical significance of the FED model. This paper seeks to explain why the nature of the empirical evidence is mixed. Our belief is that the nature of the FED model relation is time-varying and that this time-variation is linked to the level of the real bond yield. Specifically, a higher bond yield, which reflects normal economic conditions and inflation, is linked to lower bond and equity prices. As the bond yield and inflation falls, so bond and equity prices will rise, however, at very low levels of the bond yield, and a potential deflation, then the bond price will still rise but the equity price may fall due to poor economic prospects.

Using data from the G7 markets and panel regression techniques, we report evidence of a positive relation between the equity/bond yield dynamic conditional correlation and the real bond yield. This supports the view that at low levels of the bond yield the correlation between the bond and equity yield becomes negative, while, at higher levels of the bond yield, the positive relation strengthens. Evidence of this dynamic between the two yields is further supported by considering panel regressions for the FED model and the bond yield. Here, a negative slope coefficient supports the view that at low bond yield values the FED spread (between the equity and bond yield) widens as the two assets move in opposite directions, while at higher bond yield values the spread narrows and the two yields move closely together.

Given this time-varying dynamic within the FED model, we proceed to consider nonlinear panel smooth-transition models in addition to the usual linear predictive regression for 
stock returns. Results from the linear model suggest a switch in the slope coefficient from positive to negative as we examine returns over longer horizons. We suggest an explanation for this changing behaviour might be rooted in a business cycle effect where the FED spread is negatively correlated with economic conditions. The panel regressions reveal a change in behaviour according to the value of the bond yield, which acts as the transition variable. Here, we observe a weakening effect of the FED model at more extreme values of the bond yield.

The results presented in this paper are a step towards a fuller understanding of the relation between the equity and bond markets. Notably, empirical evidence in favour of the FED model as a predictor for future stock returns is mixed. Our results suggest that this mixed nature of the results arises because the strength of the relation underlying the FED model varies over time with the level of the bond yield. This in turn, is linked to the differing effects of risk and inflation on the two markets. It is hoped, therefore, that the results presented here will be of interest to both market practitioner, who will be interested in the potential for the FED model to aid in market timing strategies, and academics seeking to understand how markets interlink. 


\section{$\underline{\text { References }}$}

Andersson, M., Krylova, E., Vähämaa, S., (2008), 'Why does the correlation between stock and bond returns vary over time?', Applied Financial Economics, 18, 139-151.

Artis, M.J., Kontolemis, Z.G., Osborn, D.R., (1997), ,Business Cycles for G7 and European Countries', The Journal of Business, 70, 2, 249-279.

Asness, C, (2000), 'Stocks vs. Bonds: Explaining the Equity Risk Premium', Financial Analyst Journal, March/April.

Asness, C, (2003), 'Fight the Fed model: the relationship between future returns and stock and bond market yields', Journal of Portfolio Management, Fall, 11-24.

Baur, D., Lucey, B.M., (2009), 'Flight and contagion—an empirical analysis of stock-bond correlations', Journal of Financial Stability, 5:339-352.

Beber, A., Brandt, M.W., Kavajecz, K.A., (2009), 'Flight-to-Quality or Flight-to-Liquidity? Evidence from the Euro-Area Bond Market', The Review of Financial Studies, 22, 3, 925-957.

Bekaert, G and Engstrom, E (2010), 'Inflation and the stock market: Understanding the Fed Model', Journal of Monetary Economics, 57, 278-294.

Blanchard, O.J., (1981), 'Output, the Stock Market, and Interest Rates', The American Economic Review, 71, 1, 132-143.

Brooks, C and Persand, G, (2001), 'The trading profitability of forecasts of the gilt-equity yield ratio', International Journal of Forecasting, 17, 11-29.

Campbell, J.Y., Ammer J., (1993), 'What moves the stock and bond markets? A variance decomposition for long-term asset returns', Journal of Finance 48:3-37.

Campbell, J.Y., Lo, A.W., MacKinlay, A.C., (1997), 'The Econometrics of Financial Markets', Princeton University Press.

Campbell, J.Y., Cochrane, J.H., (2000), 'Explaining the Poor Performance of Consumptionbased Asset Pricing Models', The Journal of Finance, 55, 2, 2863-2878.

Campbell, J.Y., Shiller, R.J., (1988), 'Valuation Ratios and the Long-Run Stock Market Outlook', The Journal of Portfolio Management, Vol. 24, No. 2, 11-26.

Campbell, J.Y., Shiller, R.J., (1988), 'Valuation Ratios and the Long-Run Stock Market Outlook: An Update', NBER Working Paper Series No. 8221.

Campbell, JY and Vuolteenaho, Y, (2004), 'Inflation illusion and stock prices', American Economic Review Papers and Proceedings, 19-23.

Chiang, T. C., Li, J., Yang, S., (2015), 'Dynamic stock-bond return correlations and financial market uncertainty', Review of Quantitative Finance and Accounting, 45(1), 59-88. 
Choi, I. (2001), 'Unit Root Tests for Panel Data,' Journal of International Money and Finance, 20, 249-272.

Clare, AD, Thomas, SH and Wickens, MR, (1994), 'Is the gilt-equity yield ratio useful for predicting UK stock returns?', Economic Journal, 104, 303-315.

d'Addona, S., Kind, A.H., (2006), 'International stock-bond correlations in a simple affine asset pricing model', Journal of Banking and Finance, 30:2747-2765.

Engle, R., (2002), 'Dynamic conditional correlation: a simple class of multivariate generalized autoregressive conditional heteroskedasticity models', Journal of Business and Economic Statistics, 20, 339-350.

Estrada, J, (2006), 'The Fed model: The bad, the worse and the ugly', IESE Business School working paper.

Fisher, I. (1907), The Rate of Interest: Its Nature, Determination, and Relation to Economic Phenomena, New York: Macmillan.

Fisher, R.A. (1932), Statistical Methods for Research Workers, 4th Edition, Edinburgh: Oliver \& Boyd.

Forbes, K., \& Rigobon, R., (2002), 'No contagion, only interdependence: Measuring stock market comovements', Journal of Finance, 57, 2223-2261.

Gonzalez, A., Teräsvirta, T. and van Dijk, D. (2005). 'Panel Smooth Transition Regression Models', Research Paper Series 165, Quantitative Finance Research Centre, University of Technology, Sydney.

Gordon, M. (1962), 'The Investment, Financing, and Valuation of the Corporation', Irwin, Homewood, IL.

Gubareva, M., Borges, M.R., (2016), 'Typology for flight-to-quality episodes and downside risk measurement', Applied Economics, 48, 10, 835-853.

Gulko, L. (2002). 'Decoupling', Journal of Portfolio Management, 28, 59-66.

Hakkio, C., Keeton, W.R., (2009), 'Financial stress: what is it, how can it be measured, and why does it matter?', Federal Reserve Bank of Kansas City, Economic Review 2:5-50.

Harris, R, (2000), 'The gilt-equity yield ratio and the predictability of UK and US equity returns', Journal of Business Finance and Accounting, 27, 333-357.

Harvey, C.R., (1989), 'Forecasts of Economic Growth from the Bond and Stock Markets', Financial Analyst Journal, 45, 5, 38-45.

Hausman, J. (1978). 'Specification Tests in Econometrics', Econometrica, 46, 1251-1271. 
Humpe, A. and MacMillan, P., (2014), 'Non-linear predictability of stock market returns: Comparative evidence from Japan and the US', Investment Management and Financial Innovations, Vol. 11, Issue 4, 36-48.

Humpe, A. and McMillan D.G., (2016), 'Equity-Bond Returns Correlation and the Bond Yield: Evidence of Switching Behaviour from the G7 Markets', Credit and Capital Markets Journal, Vol. 49, Issue 3, 415-444.

Im, K.S., Pesaran, M.H., and Shin, Y. (2003), 'Testing for Unit Roots in Heterogeneous Panels,' Journal of Econometrics, 115, 53-74.

Kwan, S.H., (1996), 'Firm-specific information and the correlation between individual stocks and bonds', Journal of Financial Economics, 40:63-80.

Laubach, T. (2009), 'New Evidence on the Interest Rate Effects of Budget Deficits and Debt', Journal of the European Economic Association, Vol. 7, No. 4, pp. 858-885.

Laubach, T., and Williams, J.C. (2003), "Measuring the Natural Rate of Interest," The Review of Economics and Statistics 85(4): 1063-1070.

Levin, EJ and Wright, RE, (1998), 'The information content of the gilt-equity yield ratio', Manchester School Supplement, 66, 89-101.

Li, L. (2002), 'Macroeconomic Factors and the Correlation of Stock and Bond Returns', Yale International Center for Finance Working Paper, No 02-46.

Maddala, G.S. and Wu, S. (1999), 'A Comparative Study of Unit Root Tests with Panel Data and a New Simple Test,' Oxford Bulletin of Economics and Statistics, 61, 631-52.

Maio, P, (2013), 'The FED model and the predictability of stock returns', Review of Finance, $17,1489-1533$.

McMillan, DG, (2009), 'Are UK share prices too high: fundamental value or new era', Bulletin of Economic Research, 61, 1-20.

McMillan, DG, (2012), 'Does non-linearity help us understand, model and forecast UK stock and bond returns: evidence from the BEYR', International Review of Applied Economics, 26, $125-143$.

Ritter, J and Warr, R (2002), 'The decline of inflation and the bull market of 1982 to 1999', Journal of Financial and Quantitative Analysis, 37, 29-61.

Sharpe, S (2001), 'Re-examining stock valuation and inflation: the implications of analysts' earnings forecasts', Finance and Economic Discussion Series 200132, Board of Governors of the Federal Reserve.

Shen, P., (2000), 'The P/E Ratio and Stock Market Performance', Economic Review, Fourth Quarter, Federal Reserve Bank of Kansas City. 
Thomas, J and Zhang, F (2008), 'Don't fight the Fed model!', School of Management, Yale University, Working Paper.

Waggle, D. and Moon, G. (2005), 'Expected returns, correlations, and optimal asset allocations', Financial Services Review, 14, 253-267.

Wainscott, C.B. (1990), 'The Stock-Bond Correlation and its implications for Asset Allocation', Financial Analyst Journal, 46, 55-60. 
Table 1. Summary Statistics

\begin{tabular}{|c|c|c|c|c|c|c|c|}
\hline \multicolumn{8}{|c|}{ Monthly stock market index returns } \\
\hline Country & Germany & Canada & France & Italy & Japan & UK & US \\
\hline $\begin{array}{l}\text { DS } \\
\text { Mnemonic }\end{array}$ & TOTMKBD & TOTMKCN & TOTMKFR & TOTMKIT & TOTMKJP & TOTMKUK & TOTMKUS \\
\hline Mean & 0.0038 & 0.0046 & 0.0056 & 0.0024 & 0.0009 & 0.0052 & 0.0068 \\
\hline Std. Dev. & 0.0564 & 0.0444 & 0.0556 & 0.0645 & 0.0573 & 0.0466 & 0.0457 \\
\hline Skew & -1.0234 & -1.4980 & -0.5841 & 0.1737 & -0.3195 & -1.2007 & -1.0702 \\
\hline Kurtosis & 5.6252 & 9.0609 & 4.3277 & 3.6275 & 4.1151 & 8.2578 & 6.1593 \\
\hline \multicolumn{8}{|c|}{ Earning yields calculated from 12 month trailing PEs } \\
\hline Mean & 0.0656 & 0.0603 & 0.0723 & 0.0627 & 0.0300 & 0.0692 & 0.0558 \\
\hline Std. Dev. & 0.0149 & 0.0142 & 0.0170 & 0.0206 & 0.0166 & 0.0172 & 0.0131 \\
\hline Skew & 0.5173 & 0.9116 & 0.7681 & 2.1317 & 1.3276 & 1.2717 & 0.3965 \\
\hline Kurtosis & 2.8252 & 3.9924 & 4.1211 & 11.3210 & 3.6856 & 6.5917 & 2.8901 \\
\hline \multicolumn{8}{|c|}{10 year government bond yield } \\
\hline Country & Germany & Canada & France & Italy & Japan & UK & US \\
\hline $\begin{array}{l}\text { DS } \\
\text { Mnemonic }\end{array}$ & BMBD10Y & BMCN10Y & BMFR10Y & BMIT10Y & BMJP10Y & BMUK10Y & BMUS10Y \\
\hline Mean & 0.0506 & 0.0638 & 0.0571 & 0.0748 & 0.0256 & 0.0632 & 0.0551 \\
\hline Std. Dev. & 0.0193 & 0.0253 & 0.0236 & 0.0361 & 0.0184 & 0.0268 & 0.0201 \\
\hline Skew & 0.0254 & 0.2611 & 0.4221 & 0.5702 & 1.1543 & 0.3501 & 0.0409 \\
\hline Kurtosis & 2.3107 & 1.8398 & 1.8763 & 1.6602 & 3.3063 & 2.0383 & 2.1322 \\
\hline \multicolumn{8}{|c|}{ CPI YoY from IMF } \\
\hline Country & Germany & Canada & France & Italy & Japan & UK & US \\
\hline Mean & 0.0019 & 0.0020 & 0.0016 & 0.0027 & 0.0005 & 0.0031 & 0.0029 \\
\hline Std. Dev. & 0.0032 & 0.0035 & 0.0026 & 0.0023 & 0.0039 & 0.0050 & 0.0035 \\
\hline Skew & 0.9116 & 0.6307 & -0.0840 & 0.5079 & 0.8643 & 1.7075 & -0.6165 \\
\hline Kurtosis & 5.3546 & 9.2579 & 3.2330 & 4.2860 & 5.9647 & 1.1921 & 8.3000 \\
\hline \multicolumn{8}{|c|}{ FED Spread in \% calculated from earnings yield minus bond yield } \\
\hline Country & Germany & Canada & France & Italy & Japan & UK & US \\
\hline Mean & 1.4725 & -0.3774 & 1.5041 & -1.2313 & 0.3951 & 0.5690 & 0.0535 \\
\hline Std. Dev. & 2.8865 & 2.5430 & 2.3350 & 4.3151 & 2.9574 & 3.2871 & 2.1230 \\
\hline Skew & 0.5926 & 0.4412 & 0.8238 & 0.1535 & 0.1993 & 0.8631 & 0.9904 \\
\hline Kurtosis & 2.2871 & 2.8402 & 3.9015 & 2.8448 & 2.4545 & 3.1750 & 3.4583 \\
\hline \multicolumn{8}{|c|}{$\begin{array}{l}\text { Notes: This table presents descriptive summary statistics for equity returns, equity yields, bond } \\
\text { yields, the Fed spread and CPI for the G7 countries. The variables are on a monthly basis for the } \\
\text { sample period from January } 1986 \text { until January } 2014 \text {. For the equity markets we use broad indices } \\
\text { that cover approximately } 80 \% \text { of the market cap according to Datastream. The number of stocks in } \\
\text { the equity index are as follows: Germany (250), Canada (250), France (250), Italy (160), Japan (1000), } \\
\text { UK (550) and US (1000). }\end{array}$} \\
\hline
\end{tabular}


Table 2. G7 Panel Regressions - Equity/Bond Yield DCC and Bond Yield

\begin{tabular}{|c|c|c|c|c|c|c|c|c|c|}
\hline \multicolumn{10}{|c|}{ Pooled regression analysis for G7 (1986M5 - 2014M1): dependent variable logit DCC } \\
\hline & (a) & (b) & (c) & (d) & (e) & (f) & (g) & (h) & (i) \\
\hline Constant & $\begin{array}{l}-0.633 \\
(0.00)\end{array}$ & $\begin{array}{l}-0.632 \\
(0.00)\end{array}$ & $\begin{array}{l}-0.171 \\
(0.43)\end{array}$ & $\begin{array}{l}-0.064 \\
(0.00)\end{array}$ & $\begin{array}{l}-0.059 \\
(0.00)\end{array}$ & $\begin{array}{l}-0.028 \\
(0.22)\end{array}$ & $\begin{array}{l}-0.050 \\
(0.03)\end{array}$ & $\begin{array}{l}-0.053 \\
(0.01)\end{array}$ & $\begin{array}{l}-0.050 \\
(0.03)\end{array}$ \\
\hline $\begin{array}{l}\text { Real bond } \\
\text { yield }\end{array}$ & $\begin{array}{l}0.141 \\
(0.00)\end{array}$ & $\begin{array}{l}0.141 \\
(0.00)\end{array}$ & $\begin{array}{l}0.002 \\
(0.98)\end{array}$ & $\begin{array}{l}0.015 \\
(0.00)\end{array}$ & $\begin{array}{l}0.014 \\
(0.00)\end{array}$ & $\begin{array}{l}0.004 \\
(0.46)\end{array}$ & $\begin{array}{l}0.011 \\
(0.02) \\
\end{array}$ & $\begin{array}{l}0.012 \\
(0.04)\end{array}$ & $\begin{array}{l}0.011 \\
(0.02)\end{array}$ \\
\hline $\begin{array}{l}\text { Correlation } \\
(\mathrm{t}-1)\end{array}$ & - & - & - & $\begin{array}{l}0.913 \\
(0.00)\end{array}$ & $\begin{array}{l}0.918 \\
(0.00)\end{array}$ & $\begin{array}{l}0.911 \\
(0.00)\end{array}$ & $\begin{array}{l}0.915 \\
(0.00)\end{array}$ & $\begin{array}{l}0.908 \\
(0.00)\end{array}$ & $\begin{array}{l}0.915 \\
(0.00)\end{array}$ \\
\hline $\begin{array}{l}\text { Cross sec. } \\
\text { fixed effect }\end{array}$ & yes & no & no & yes & no & no & no & Yes & no \\
\hline $\begin{array}{l}\text { Cross sec. } \\
\text { random } \\
\text { effect }\end{array}$ & no & yes & yes & no & Yes & Yes & no & No & yes \\
\hline $\begin{array}{l}\text { Period } \\
\text { fixed effect }\end{array}$ & no & no & yes & no & No & Yes & yes & Yes & yes \\
\hline $\mathrm{R}^{2}$ & 0.120 & 0.068 & 0.425 & 0.854 & 0.854 & 0.897 & 0.841 & 0.841 & 0.841 \\
\hline \multicolumn{10}{|c|}{ Hausman test Chi-Sq. Statistic } \\
\hline $\begin{array}{l}\text { Cross sec. } \\
\text { Random }\end{array}$ & $\begin{array}{l}0.000 \\
(0.99)\end{array}$ & & & $\begin{array}{l}4.704 \\
(0.10) \\
\end{array}$ & & & & & \\
\hline $\begin{array}{l}\text { Period } \\
\text { random }\end{array}$ & & $\begin{array}{l}3.449 \\
(0.06)\end{array}$ & & & $\begin{array}{l}0.000 \\
(1.00)\end{array}$ & & & & \\
\hline $\begin{array}{l}\text { Cross sec. } \\
\text { and period } \\
\text { random }\end{array}$ & & & $\begin{array}{l}3.322 \\
(0.07)\end{array}$ & & & $\begin{array}{l}0.000 \\
(1.00)\end{array}$ & & & \\
\hline \multicolumn{10}{|c|}{$\begin{array}{l}\text { Notes: This table reports pooled regression results of equation (5) to establish the relation } \\
\text { between the real equity/bond yield DCC correlation and the real bond yield for the G7 sample. } \\
\text { Column (a) presents results where the pooled regression includes cross section fixed effects, } \\
\text { column (b) with cross section random effects and column (c) with period fixed effects and } \\
\text { cross section random effects. To assess the reliability of the model, the Hausman test for } \\
\text { random effects in the cross section, period random effects as well as cross section and period } \\
\text { random effects is reported in the lower part of the table. Finally, columns (g) to (i) show } \\
\text { results for the panel regression including the lagged dependent variable. To account for } \\
\text { heteroscedasticity and autocorrelation, we apply White period standard errors and covariance. } \\
\text { The numbers in parentheses are } p \text {-values. }\end{array}$} \\
\hline
\end{tabular}


Table 3. G7 Panel Regression - Cross Section Fixed Effects and AR(1).

\begin{tabular}{|c|c|c|c|c|}
\hline \multicolumn{5}{|c|}{$\begin{array}{c}\text { G7 pooled regression analysis with cross section fixed effects and country specific AR(1) } \\
\text { terms }(1986 \mathrm{M} 5-2014 \mathrm{M} 1) \text { : Dependent variable: logit DCC }\end{array}$} \\
\hline Variable & Coefficient & Standard Error & t-Statistic & Probability \\
\hline Constant & -0.628 & 0.023 & -27.77 & 0.00 \\
\hline Real bond yield & 0.141 & 0.006 & 24.41 & 0.00 \\
\hline AR(1) Germany & 0.902 & 0.022 & 40.74 & 0.00 \\
\hline AR(1) Canada & 0.916 & 0.017 & 53.82 & 0.00 \\
\hline AR(1) France & 0.912 & 0.019 & 46.77 & 0.00 \\
\hline AR(1) Italy & 0.858 & 0.025 & 34.98 & 0.00 \\
\hline AR(1) Japan & 0.886 & 0.020 & 44.49 & 0.00 \\
\hline AR(1) UK & 0.932 & 0.016 & 57.92 & 0.00 \\
\hline AR(1) US & 0.950 & 0.014 & 66.56 & 0.00 \\
\hline \multicolumn{5}{|c|}{ Fixed effects (cross): } \\
\hline Germany & -0.471 & Japan & 0.147 & \\
\hline Canada & 0.071 & $\mathrm{UK}$ & -0.199 & \\
\hline France & 0.279 & US & 0.241 & \\
\hline Italy & -0.069 & R-squared & 0.850 & \\
\hline
\end{tabular}


Table 4. G7 Panel Regressions - FED Model and Bond Yield

\begin{tabular}{|c|c|c|c|c|c|c|c|c|c|}
\hline \multicolumn{10}{|c|}{$\begin{array}{l}\text { G7 pooled regression analysis with alternate cross section and time series effects } \\
\qquad(1986 \mathrm{M} 1-2014 \mathrm{M} 1) \text { : Dependent variable: FED Model }\end{array}$} \\
\hline & (a) & (b) & (c) & (d) & (e) & (f) & (g) & (h) & (i) \\
\hline Constant & $\begin{array}{l}4.391 \\
(0.00)\end{array}$ & \begin{tabular}{|l|}
4.387 \\
$(0.00)$
\end{tabular} & $\begin{array}{l}1.674 \\
(0.01)\end{array}$ & $\begin{array}{l}0.315 \\
(0.00)\end{array}$ & $\begin{array}{l}0.241 \\
(0.00)\end{array}$ & $\begin{array}{l}0.104 \\
(0.02)\end{array}$ & $\begin{array}{l}0.131 \\
(0.01)\end{array}$ & $\begin{array}{l}0.191 \\
(0.00)\end{array}$ & $\begin{array}{l}0.131 \\
(0.01)\end{array}$ \\
\hline $\begin{array}{l}\text { Real bond } \\
\text { yield }\end{array}$ & $\begin{array}{l}-1.209 \\
(0.00)\end{array}$ & \begin{tabular}{|l|}
-1.208 \\
$(0.00)$
\end{tabular} & $\begin{array}{l}-0.393 \\
(0.06)\end{array}$ & $\begin{array}{l}-0.083 \\
(0.00)\end{array}$ & $\begin{array}{l}-0.062 \\
(0.00) \\
\end{array}$ & $\begin{array}{l}-0.022 \\
(0.10)\end{array}$ & $\begin{array}{l}-0.030 \\
(0.02)\end{array}$ & $\begin{array}{l}-0.047 \\
(0.00)\end{array}$ & $\begin{array}{l}-0.030 \\
(0.02)\end{array}$ \\
\hline FED (t-1) & - & - & - & $\begin{array}{l}0.943 \\
(0.00)\end{array}$ & $\begin{array}{l}0.956 \\
(0.00)\end{array}$ & $\begin{array}{l}0.966 \\
(0.00)\end{array}$ & $\begin{array}{l}0.967 \\
(0.00)\end{array}$ & $\begin{array}{l}0.953 \\
(0.00)\end{array}$ & $\begin{array}{l}0.967 \\
(0.00)\end{array}$ \\
\hline $\begin{array}{l}\text { Cross sec. } \\
\text { fixed effect }\end{array}$ & Yes & no & No & Yes & no & No & No & Yes & No \\
\hline $\begin{array}{l}\text { Cross sec. } \\
\text { random } \\
\text { effect }\end{array}$ & No & Yes & Yes & No & Yes & Yes & No & No & Yes \\
\hline $\begin{array}{l}\text { Period } \\
\text { fixed effect }\end{array}$ & No & No & Yes & No & No & Yes & Yes & Yes & Yes \\
\hline$R^{2}$ & 0.628 & 0.593 & 0.853 & 0.973 & 0.973 & 0.989 & 0.959 & 0.960 & 0.959 \\
\hline & \multicolumn{9}{|c|}{ Hausman test Chi-Sq. Statistic } \\
\hline $\begin{array}{l}\text { Cross sec. } \\
\text { Random }\end{array}$ & $\begin{array}{l}0.000 \\
(1.00)\end{array}$ & & & $\begin{array}{l}17.911 \\
(0.00)\end{array}$ & & & & & \\
\hline $\begin{array}{l}\text { Period } \\
\text { random }\end{array}$ & & \begin{tabular}{|l|}
44.180 \\
$(0.00)$
\end{tabular} & & & $\begin{array}{l}0.000 \\
(1.00)\end{array}$ & & & & \\
\hline $\begin{array}{l}\text { Cross sec. } \\
\text { and period } \\
\text { random }\end{array}$ & & & $\begin{array}{l}44.334 \\
(0.00)\end{array}$ & & & $\begin{array}{l}0.000 \\
(1.00)\end{array}$ & & & \\
\hline \multicolumn{10}{|c|}{$\begin{array}{l}\text { Notes: This table reports pooled regression results to establish the relation between the FED } \\
\text { model and the real bond yield for the G7 sample. Column (a) presents results where the pooled } \\
\text { regression includes cross section fixed effects, column (b) with cross section random effects } \\
\text { and column (c) with period fixed effects and cross section random effects. To assess the } \\
\text { reliability of the model, the Hausman test for random effects in the cross section, period } \\
\text { random effects as well as cross section and period random effects is reported in the lower part } \\
\text { of the table. Finally, columns (g) to (i) show results for the panel regression including the } \\
\text { lagged dependent variable. To account for heteroscedasticity and autocorrelation, we apply } \\
\text { White period standard errors and covariance. The numbers in parentheses are } p \text {-values. }\end{array}$} \\
\hline
\end{tabular}


Table 5. G7 FED Model and Bond Yield - Cross Section Fixed Effects and AR(1).

\begin{tabular}{|c|c|c|c|c|}
\hline \multicolumn{5}{|c|}{$\begin{array}{l}\text { G7 pooled regression analysis with cross section fixed effects and country specific AR(1) } \\
\text { terms (1986M1 - 2014M1): Dependent variable: FED Model }\end{array}$} \\
\hline Variable & Coefficient & Standard Error & t-Statistic & Probability \\
\hline Constant & 4.344 & 0.052 & 83.57 & 0.00 \\
\hline Real bond yield & -1.194 & 0.012 & -102.29 & 0.00 \\
\hline AR(1) Germany & 0.949 & 0.021 & 46.00 & 0.00 \\
\hline AR(1) Canada & 0.909 & 0.025 & 36.38 & 0.00 \\
\hline AR(1) France & 0.908 & 0.041 & 21.90 & 0.00 \\
\hline AR(1) Italy & 0.958 & 0.033 & 29.06 & 0.00 \\
\hline AR(1) Japan & 0.975 & 0.014 & 71.10 & 0.00 \\
\hline AR(1) UK & 0.946 & 0.026 & 36.64 & 0.00 \\
\hline AR(1) US & 0.930 & 0.027 & 34.05 & 0.00 \\
\hline \multicolumn{5}{|c|}{ Fixed effects (cross): } \\
\hline Germany & 0.966 & Japan & -1.376 & \\
\hline Canada & 0.041 & UK & 0.342 & \\
\hline France & 1.681 & US & -1.043 & \\
\hline Italy & -0.611 & R-squared & 0.962 & \\
\hline
\end{tabular}


Table 6. G7 Panel Regressions - adjusted FED Model and Bond Yield

\begin{tabular}{|c|c|c|c|c|c|c|c|c|c|}
\hline \multicolumn{10}{|c|}{$\begin{array}{l}\text { G7 pooled regression analysis with alternate cross section and time series effects } \\
(1986 \mathrm{M} 1-2014 \mathrm{M} 1) \text { : Dependent variable: Adjusted FED Model }\end{array}$} \\
\hline & (a) & (b) & (c) & (d) & (e) & (f) & (g) & (h) & (i) \\
\hline Constant & $\begin{array}{l}6.374 \\
(0.00)\end{array}$ & $\begin{array}{l}6.369 \\
(0.00)\end{array}$ & $\begin{array}{l}5.576 \\
(0.00)\end{array}$ & $\begin{array}{l}0.738 \\
(0.00)\end{array}$ & $\begin{array}{l}0.436 \\
(0.00)\end{array}$ & $\begin{array}{l}0.301 \\
(0.06)\end{array}$ & $\begin{array}{l}0.334 \\
(0.07)\end{array}$ & $\begin{array}{l}0.778 \\
(0.00)\end{array}$ & $\begin{array}{l}0.332 \\
(0.07)\end{array}$ \\
\hline $\begin{array}{l}\text { Real bond } \\
\text { yield }\end{array}$ & $\begin{array}{l}-1.129 \\
(0.00)\end{array}$ & $\begin{array}{l}-1.128 \\
(0.00)\end{array}$ & $\begin{array}{l}-0.890 \\
(0.00)\end{array}$ & $\begin{array}{l}-0.139 \\
(0.00)\end{array}$ & $\begin{array}{l}-0.080 \\
(0.00)\end{array}$ & $\begin{array}{l}-0.051 \\
(0.05)\end{array}$ & $\begin{array}{l}-0.059 \\
(0.01)\end{array}$ & $\begin{array}{l}-0.145 \\
(0.00)\end{array}$ & $\begin{array}{l}-0.058 \\
(0.01)\end{array}$ \\
\hline $\begin{array}{l}\text { Adjusted } \\
\text { FED (t-1) }\end{array}$ & - & - & - & $\begin{array}{l}0.899 \\
(0.00)\end{array}$ & $\begin{array}{l}0.940 \\
(0.00)\end{array}$ & $\begin{array}{l}0.954 \\
(0.00)\end{array}$ & $\begin{array}{l}0.952 \\
(0.00)\end{array}$ & $\begin{array}{l}0.890 \\
(0.0000)\end{array}$ & $\begin{array}{l}0.952 \\
(0.00)\end{array}$ \\
\hline $\begin{array}{l}\text { Cross sec. } \\
\text { fixed effect }\end{array}$ & Yes & No & No & Yes & no & No & No & Yes & No \\
\hline $\begin{array}{l}\text { Cross sec. } \\
\text { random } \\
\text { effect }\end{array}$ & No & Yes & Yes & No & Yes & Yes & No & No & Yes \\
\hline $\begin{array}{l}\text { Period } \\
\text { fixed effect }\end{array}$ & No & No & Yes & No & No & Yes & Yes & Yes & Yes \\
\hline $\mathrm{R}^{2}$ & 0.675 & 0.638 & 0.862 & 0.959 & 0.958 & 0.979 & 0.942 & 0.945 & 0.942 \\
\hline & \multicolumn{9}{|c|}{ Hausman test Chi-Sq. Statistic } \\
\hline $\begin{array}{l}\text { Cross sec. } \\
\text { Random }\end{array}$ & $\begin{array}{l}0.000 \\
(1.00)\end{array}$ & & & $\begin{array}{l}0.000 \\
(1.00)\end{array}$ & & & & & \\
\hline $\begin{array}{l}\text { Period } \\
\text { random }\end{array}$ & & $\begin{array}{l}1.499 \\
(0.22)\end{array}$ & & & $\begin{array}{l}0.000 \\
(1.00)\end{array}$ & & & & \\
\hline $\begin{array}{l}\text { Cross sec. } \\
\text { and period } \\
\text { random }\end{array}$ & & & $\begin{array}{l}1.509 \\
(0.22)\end{array}$ & & & $\begin{array}{l}0.000 \\
(1.00)\end{array}$ & & & \\
\hline \multicolumn{10}{|c|}{$\begin{array}{l}\text { Notes: This table reports pooled regression results to establish the relation between the } \\
\text { adjusted FED model and the real bond yield for the G7 sample. Column (a) presents results } \\
\text { where the pooled regression includes cross section fixed effects, column (b) with cross section } \\
\text { random effects and column (c) with period fixed effects and cross section random effects. To } \\
\text { assess the reliability of the model, the Hausman test for random effects in the cross section, } \\
\text { period random effects as well as cross section and period random effects is reported in the } \\
\text { lower part of the table. Finally, columns (g) to (i) show results for the panel regression } \\
\text { including the lagged dependent variable. To account for heteroscedasticity and autocorrelation, } \\
\text { we apply White period standard errors and covariance. The numbers in parentheses are } p \text { - } \\
\text { values. }\end{array}$} \\
\hline
\end{tabular}


Table 7. G7 adj. FED Model and Bond Yield - Cross Section Fixed Effects and AR(1).

\begin{tabular}{|l|c|c|c|c|}
\hline $\begin{array}{l}\text { G7 pooled regression analysis with cross section fixed effects and country specific AR(1) } \\
\text { terms (1986M1 - 2014M1): Dependent variable: adjusted FED Model }\end{array}$ \\
\hline Variable & Coefficient & Standard Error & t-Statistic & Probability \\
\hline Constant & 6.381 & 0.012 & 523.38 & 0.00 \\
\hline Real bond yield & -1.132 & 0.004 & -308.40 & 0.00 \\
\hline AR(1) Germany & 0.939 & 0.002 & 631.27 & 0.00 \\
\hline AR(1) Canada & 0.962 & 0.001 & 906.22 & 0.00 \\
\hline AR(1) France & 0.949 & 0.001 & 644.12 & 0.00 \\
\hline AR(1) Italy & 0.949 & 0.000 & 5740.29 & 0.00 \\
\hline AR(1) Japan & 0.987 & 0.001 & 850.62 & 0.00 \\
\hline AR(1) UK & 0.963 & 0.001 & 704.80 & 0.00 \\
\hline AR(1) US & 0.970 & 0.001 & 815.03 & 0.00 \\
\hline Fixed effects (cross): & 0.602 & Japan & -3.092 & \\
\hline Germany & 0.1683 & UK \\
\hline Canada & 1.341 & US \\
\hline France & 0.439 & R-squared & 0.974 & \\
\hline Italy & \multicolumn{5}{|c|}{} \\
\hline \multicolumn{5}{|l|}{$\begin{array}{l}\text { Notes: See the entries from Table 6. The values are from the panel regression given by } \\
\text { equation (5), with fixed effects for the cross section only and country specific AR(1) terms. }\end{array}$} \\
\hline
\end{tabular}


Table 8. FED Model G7 Predictability

\begin{tabular}{|c|c|c|c|c|c|}
\hline \multicolumn{6}{|c|}{ Linear Model with Cross Section Fixed Effects } \\
\hline & $1 \mathrm{Y}$ & $2 Y$ & $3 Y$ & $5 Y$ & $10 Y$ \\
\hline C & $\begin{array}{l}0.022 \\
{[0.00]}\end{array}$ & $\begin{array}{l}0.007 \\
{[0.00]}\end{array}$ & $\begin{array}{l}0.003 \\
{[0.00]}\end{array}$ & $\begin{array}{l}0.022 \\
{[0.00]}\end{array}$ & $\begin{array}{l}0.009 \\
{[0.02]}\end{array}$ \\
\hline FED & $\begin{array}{l}0.494 \\
{[0.04]} \\
\end{array}$ & $\begin{array}{l}0.325 \\
{[0.03]}\end{array}$ & $\begin{array}{l}-0.046 \\
{[0.81]}\end{array}$ & $\begin{array}{l}-0.980 \\
{[0.00]}\end{array}$ & $\begin{array}{l}-0.417 \\
{[0.21]}\end{array}$ \\
\hline $\mathrm{R}^{2}(\%) / \mathrm{RSS}$ & $1.57 / 99.872$ & $3.32 / 54.53$ & $4.97 / 36.72$ & $13.07 / 74.99$ & $25.22 / 3.0822$ \\
\hline \multicolumn{6}{|c|}{ Panel Smooth Transition Model with RBY as Transition Variable and Cross Section Fixed Effects } \\
\hline $\begin{array}{l}\text { FED (inner) } \\
\beta_{1}\end{array}$ & $\begin{array}{l}3.488 \\
(14.67) \\
{[0.0000]}\end{array}$ & $\begin{array}{l}2.686 \\
(18.24) \\
{[0.00]}\end{array}$ & $\begin{array}{l}1.418 \\
(14.90) \\
{[0.00]}\end{array}$ & $\begin{array}{l}4.340 \\
(5.20) \\
{[0.00]} \\
\end{array}$ & $\begin{array}{l}0.451 \\
(5.14) \\
{[0.00]}\end{array}$ \\
\hline $\begin{array}{l}\text { FED (outer) } \\
\beta_{2}\end{array}$ & $\begin{array}{l}-3.022 \\
(-8.92) \\
{[0.00]}\end{array}$ & $\begin{array}{l}-1.290 \\
(-6.72) \\
{[0.00]}\end{array}$ & $\begin{array}{l}-0.731 \\
(-6.19) \\
{[0.00]}\end{array}$ & $\begin{array}{l}-6.932 \\
(-4.26) \\
{[0.00]}\end{array}$ & $\begin{array}{l}-0.264 \\
(-2.25) \\
{[0.02]}\end{array}$ \\
\hline Gamma $\gamma$ & $\begin{array}{l}7211.36 \\
(7.54) \\
{[0.00]}\end{array}$ & $\begin{array}{l}4123.584 \\
(0.19) \\
{[0.85]}\end{array}$ & $\begin{array}{l}5539.154 \\
(0.59) \\
{[0.56]}\end{array}$ & $\begin{array}{l}118.950 \\
(1.98) \\
{[0.05]}\end{array}$ & $\begin{array}{l}1847.128 \\
(0.18) \\
{[0.86]}\end{array}$ \\
\hline $\mathrm{C}_{1}$ & $\begin{array}{l}0.020 \\
(2.26) \\
{[0.02]} \\
\end{array}$ & $\begin{array}{l}0.012 \\
(0.23) \\
{[0.82]} \\
\end{array}$ & $\begin{array}{l}0.018 \\
(0.16) \\
{[0.87]} \\
\end{array}$ & $\begin{array}{l}0.037 \\
(0.00) \\
{[0.99]} \\
\end{array}$ & $\begin{array}{l}0.044 \\
(0.00) \\
{[0.99]} \\
\end{array}$ \\
\hline $\mathrm{C}_{2}$ & $\begin{array}{l}0.086 \\
(3.37) \\
{[0.00]}\end{array}$ & $\begin{array}{l}0.062 \\
(0.68) \\
{[0.50]}\end{array}$ & $\begin{array}{l}0.067 \\
(0.83) \\
{[0.40]}\end{array}$ & $\begin{array}{l}0.037 \\
(0.00) \\
{[0.99]}\end{array}$ & $\begin{array}{l}0.044 \\
(0.00) \\
{[0.99]}\end{array}$ \\
\hline $\mathrm{R}^{2}(\%) / \mathrm{RSS}$ & $8.75 / 16.07$ & $14.60 / 3.9878$ & $10.11 / 1.6870$ & $10.20 / 0.6411$ & $4.50 / 0.1073$ \\
\hline \multicolumn{6}{|c|}{ Panel Smooth Transition Model with FED as Transition Variable and Cross Section Fixed Effects } \\
\hline $\begin{array}{l}\text { FED (inner) } \\
\beta_{1}\end{array}$ & $\begin{array}{l}-3.01 \\
(-4.24) \\
{[0.00]} \\
\end{array}$ & $\begin{array}{l}1.323 \\
(7.62) \\
{[0.00]} \\
\end{array}$ & $\begin{array}{l}1.695 \\
(4.80) \\
{[0.00]} \\
\end{array}$ & $\begin{array}{l}0.618 \\
(8.78) \\
{[0.00]} \\
\end{array}$ & $\begin{array}{l}0.223 \\
(6.37) \\
{[0.00]} \\
\end{array}$ \\
\hline $\begin{array}{ll}\text { FED } & \text { (outer) } \\
\beta_{2} & \end{array}$ & $\begin{array}{l}5.975 \\
(8.26) \\
{[0.00]}\end{array}$ & $\begin{array}{l}1.136 \\
(5.29) \\
{[0.00]}\end{array}$ & $\begin{array}{l}-0.730 \\
(-1.91) \\
{[0.06]}\end{array}$ & $\begin{array}{l}0.263 \\
(3.96) \\
{[0.00]}\end{array}$ & $\begin{array}{l}0.127 \\
(3.21) \\
{[0.00]}\end{array}$ \\
\hline Gamma $\gamma$ & $\begin{array}{l}3846.097 \\
(3.83) \\
{[0.00]}\end{array}$ & $\begin{array}{l}443.598 \\
(0.06) \\
{[0.95]}\end{array}$ & $\begin{array}{l}794.876 \\
(52.96) \\
{[0.00]}\end{array}$ & $\begin{array}{l}218385.306 \\
(3.17) \\
{[0.00]}\end{array}$ & $\begin{array}{l}40185.486 \\
(0.37) \\
{[0.71]}\end{array}$ \\
\hline $\mathrm{C}_{1}$ & $\begin{array}{l}0.038 \\
(0.29) \\
{[0.77]} \\
\end{array}$ & $\begin{array}{l}-0.180 \\
(-0.07) \\
{[0.95]} \\
\end{array}$ & $\begin{array}{l}-0.039 \\
(-0.01) \\
{[0.99]} \\
\end{array}$ & $\begin{array}{l}-0.084 \\
(-20.77) \\
{[0.00]}\end{array}$ & $\begin{array}{l}-0.058 \\
(-0.64) \\
{[0.52]} \\
\end{array}$ \\
\hline $\mathrm{C}_{2}$ & $\begin{array}{l}0.039 \\
(0.28) \\
{[0.78]} \\
\end{array}$ & $\begin{array}{l}0.044 \\
(0.28) \\
{[0.78]} \\
\end{array}$ & $\begin{array}{l}-0.039 \\
(-0.01) \\
{[0.99]} \\
\end{array}$ & $\begin{array}{l}0.041 \\
(13.87) \\
{[0.00]} \\
\end{array}$ & $\begin{array}{l}0.659 \\
(0.31) \\
{[0.76]} \\
\end{array}$ \\
\hline $\mathrm{R}^{2}(\%) / \mathrm{RSS}$ & $8.69 / 16.15$ & $13.96 / 4.0178$ & $8.67 / 1.7140$ & $10.08 / 0.6419$ & $4.82 / 0.10696$ \\
\hline $\begin{array}{l}\text { Notes: In the } u \\
\text { estimate the re } \\
\text { horizons. The } \\
\text { allowing for tv } \\
\text { part of the tabl } \\
\text { transition poin }\end{array}$ & $\begin{array}{l}\text { pper part of th } \\
\text { lationship betv } \\
\text { niddle part of } \\
\text { o transition p } \\
\text { reports the re } \\
\text { s for the FED }\end{array}$ & $\begin{array}{l}\text { le, a linear par } \\
\text { the FED sprea } \\
\text { able reports th } \\
\text { for the real bo } \\
\text { of a panel sm } \\
\text { ad as transitior }\end{array}$ & $\begin{array}{l}\text { l regression is } \\
\text { and future sto } \\
\text { results of a pa } \\
\text { d yield as tran } \\
\text { oth transition } \\
\text { variable. The }\end{array}$ & $\begin{array}{l}\text { pplied to the G7 } \\
\text { k market returns } \\
\text { l smooth transit } \\
\text { tion variable. Fi } \\
\text { gression allowin } \\
\text { mbers in ( ) par }\end{array}$ & $\begin{array}{l}\text { ample to } \\
\text { t different } \\
\text { on regression } \\
\text { lly, the lower } \\
\text { for two } \\
\text { theses are } t \text { - }\end{array}$ \\
\hline
\end{tabular}


Table 9: PE Model G7 Predictability

\begin{tabular}{|l|l|l|l|l|l|}
\hline \multicolumn{7}{|c|}{ PE Model with cross section fixed effects } \\
\hline & $1 Y$ & $2 Y$ & $3 Y$ & $5 Y$ & $10 Y$ \\
\hline $\mathrm{C}$ & -0.005 & 0.025 & 0.031 & 0.060 & 0.084 \\
& $(-0.11)$ & $(0.53)$ & $(0.72)$ & $(0.84)$ & $(2.13)$ \\
& {$[0.91]$} & {$[0.60]$} & {$[0.47]$} & {$[0.40]$} & {$[0.03]$} \\
\hline $\mathrm{PE}$ & 0.001 & -0.001 & -0.001 & -0.002 & -0.003 \\
& $(0.59)$ & $(-0.36)$ & $(-0.65)$ & $(-0.49)$ & $(-1.77)$ \\
& {$[0.56]$} & {$[0.72]$} & {$[0.52]$} & {$[0.62]$} & {$[0.08]$} \\
\hline $\mathrm{R}^{2}(\%) /$ RSS & $1.34 / 100.1060$ & $3.11 / 54.65$ & $5.50 / 36.52$ & $11.80 / 76.09$ & $36.67 / 2.6102$ \\
\hline Notes: The table shows a linear panel regression to estimate the relationship between the price to \\
earnings ratio (PE) and future stock market returns at different horizons for the G7 sample. The \\
numbers in ( ) parentheses are $t$-values and in [ ] parentheses show p-values. \\
\hline
\end{tabular}


Figure 1. Rolling Equity/Bond Yield Correlations
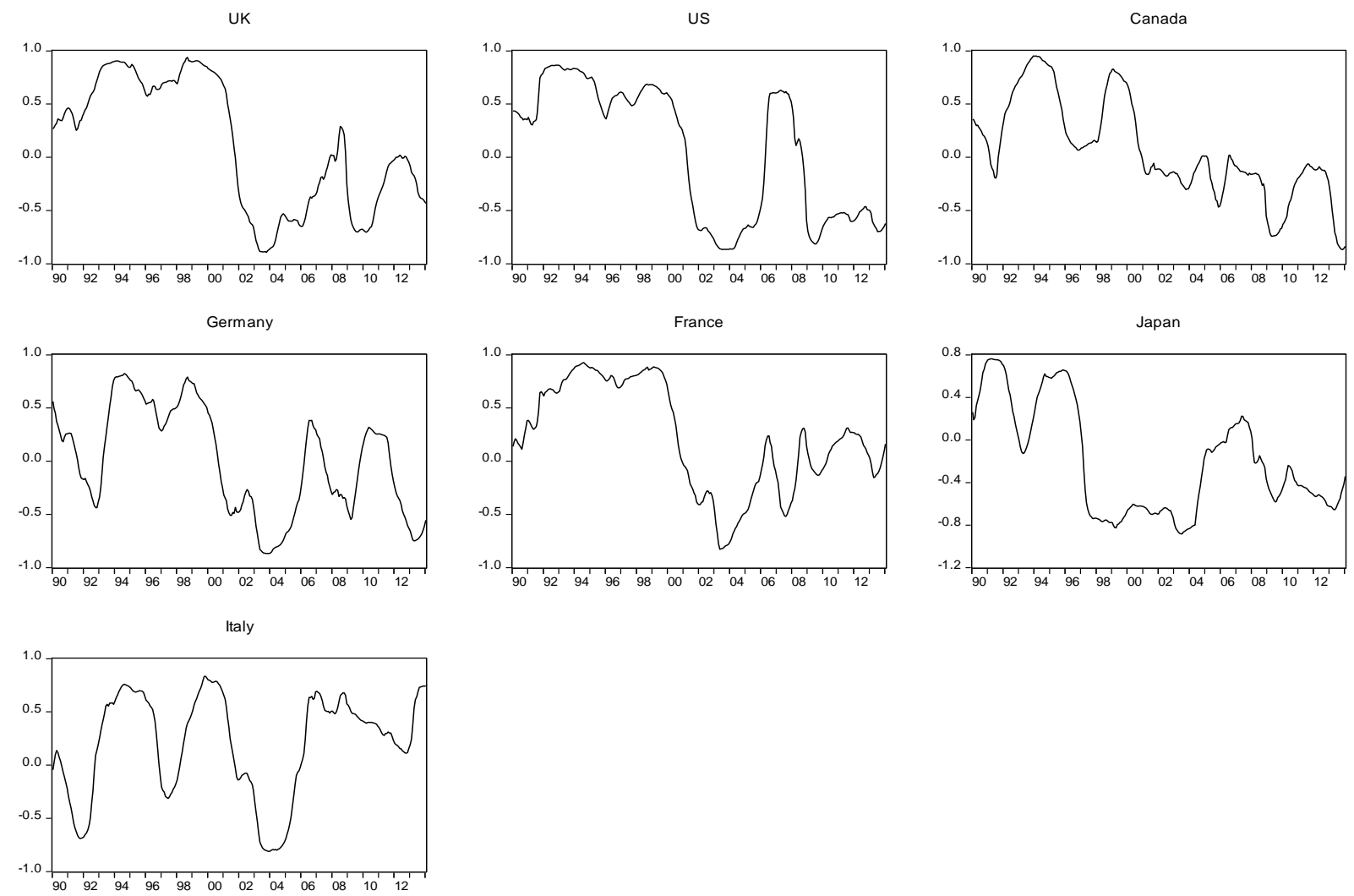
Figure 2. DCC Equity/Bond Yield Correlation

LDCC_BD

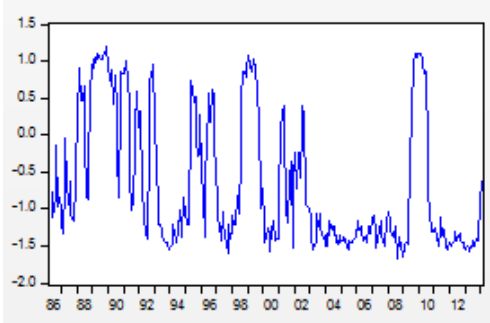

LDCC_IT

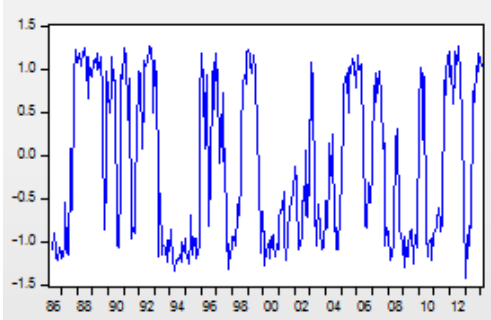

LDDC_US



LDCC_CA

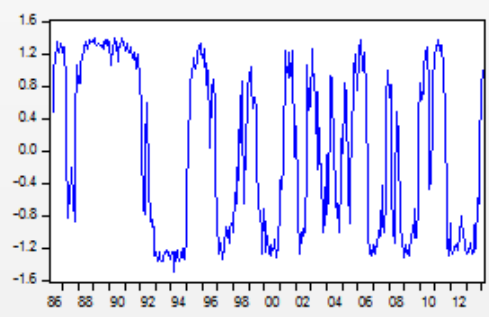

LDCC_JP

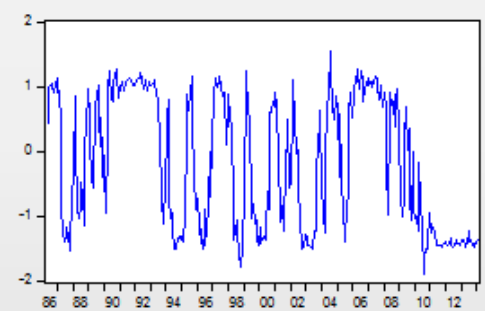

LDCC_FR



LDCC_UK

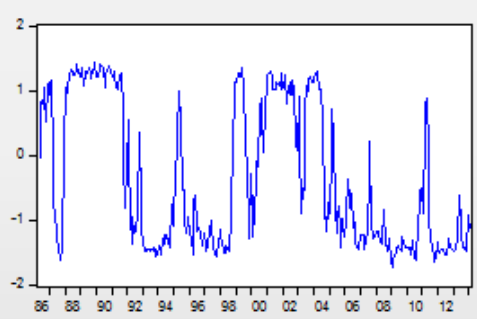

\section{Appendix A: DCC correlation}

The $\mathrm{DCC}(1,1)$ model is given by:

$r_{i, t}=\gamma_{i}+\phi_{i} r_{i, t-1}+\varepsilon_{i, t}$

$\sigma_{i, t}^{2}=\varpi_{i}+\alpha_{i} \varepsilon_{i, t-1}^{2}+\beta_{i} \sigma_{i, t-1}^{2}$

$\sigma_{i j, t}=\bar{\sigma}_{i j}+\alpha\left(\tau_{i, t-1} \tau_{j, t-1}-\bar{\sigma}_{i j}\right)+\beta\left(\sigma_{i j, t-1}-\bar{\sigma}_{i j}\right)$

Where $r_{i, t}$ and $\sigma_{i, t}$ is the asset $i$ return and conditional volatility respectively at time $t$, while $\sigma_{i j, t}$ is the conditional covariance between assets $i$ and $j$ at time $t$. The term $\tau_{i, t}=r_{i, t} / \sigma_{i, t}$ and $\bar{\sigma}_{i, t}$ is the unconditional expectation of the cross product of $\tau_{i, t} \tau_{j, t}$. Akin to the GARCH model itself, the 
DCC thus depends on the innovation to the correlation, $\alpha$, and the persistence of last periods correlation, $\beta$.

\section{Appendix B: panel unit root tests}

The panel unit root tests are based on the following ADF autoregression:

$\Delta z_{i, t}=\alpha_{i}+\rho_{i} z_{i, t-1}+\sum_{j=1}^{k_{i}} \beta_{i j} \Delta z_{i, t-j}+\eta_{\mathrm{i}, \mathrm{t}}$

Where $z$ is the series of interest, in this case the logit transformed conditional dynamic correlation. The heterogeneous panel unit root test developed by Im, Pesaran and Shin (2003) has a null hypothesis $H_{0}: \rho_{i}=0$ for all $i$ is tested against the alternative $H_{1}: \rho_{i}<0$ for some (but not necessarily all) $i$. A separate ADF test is specified for each cross-section, where the test statistic is the arithmetic mean (across $i$ ) of the $\mathrm{N}$ individual ADF t-statistics on $\rho_{i}$. The test statistic follows a normal distribution. Numerical values for the mean and variance, conditional on $p_{i}=1$, are generated by Monte Carlo simulation, and are tabulated by Im, Pesaran and Shin. The panel unit root tests based on Fisher (1932) are constructed in the same manner, but the tests are based on combining the $p$-values from the individual ADF tests, rather than the $t$-values, see Maddala and $\mathrm{Wu}(1999)$ and Choi (2001). 